\begin{tabular}{|c|c|c|}
\hline 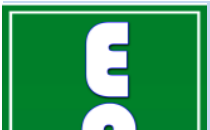 & $\begin{array}{l}\text { International Journal of Current Research in } \\
\text { Biosciences and Plant Biology }\end{array}$ & $=$ \\
\hline & Volume $5 \bullet$ Number 1 (January-2018) • ISSN: 2349-8080 (Online) & \\
\hline $\begin{array}{l}\text { EXCELLENT } \\
\text { PUBLISHERS }\end{array}$ & Journal homepage: www.ijcrbp.com & \\
\hline
\end{tabular}

Original Research Article

doi: https://doi.org/10.20546/ijcrbp.2018.501.008

\title{
Antimicrobial and Anticancer Activity of Green Gram (Vigna radiata) and Callus of Green Gram
}

\author{
R. Gautami and Priya Iyer* \\ PG and Research Department of Biotechnology, Women's Christian College, \\ Chennai-600 006, Tamil Nadu, India
}

${ }^{*}$ Corresponding author.

\begin{tabular}{|c|c|}
\hline Article Info & ABSTRACT \\
\hline $\begin{array}{l}\text { Date of Acceptance: } \\
07 \text { October } 2017\end{array}$ & \multirow{4}{*}{$\begin{array}{l}\text { The green gram seeds were collected from the market and its antimicrobial and } \\
\text { anticancer activity was studied. Green gram plays an important role in our day to day } \\
\text { life. It is mainly used as sun tan and skin moisturizers. In this study the bacteria } \\
\text { involved in skin infections are isolated and treated against the green gram to evaluate } \\
\text { its susceptibility using antimicrobial activity. Using plant tissue culture technique the } \\
\text { callus of green gram was also isolated and the study was done to compare both green } \\
\text { gram and callus of green gram. Research has been developing to evaluate green gram } \\
\text { as a anticancer agent. In this study the anticancer activity of green gram was performed } \\
\text { using MTT assay method to evaluate its cytotoxicity against the cancer and Vero cell } \\
\text { lines. Lectin is one of the major active compounds in green gram. It is purified and its } \\
\text { activity was performed using hemeagglutination method. }\end{array}$} \\
\hline $\begin{array}{l}\text { Date of Publication: } \\
\text { 06 January } 2018\end{array}$ & \\
\hline Keywords & \\
\hline $\begin{array}{l}\text { Antimicrobial activity } \\
\text { Callus extract } \\
\text { Cytotoxicity } \\
\text { Phytochemicals } \\
\text { Vigna radiata }\end{array}$ & \\
\hline
\end{tabular}

\section{Introduction}

Green gram is also known as Mung Bean, Mong dhal, golden gram, green soy etc., The beans are small in size, ovoid in shape and green in colour. The word "mung" is derived from a Hindi word known as "moong". The mung bean is the species which as moved from the genus Phaseolus to Vigna. But it is often called Phaseolus aureus or Phaseolus radiatus. The main role of green gram is that it helps in reducing weight, lowers the blood pressure etc., the gram flour obtained from green gram is used brighten the skin, used to remove the facial hair, removes the sun tan, prevents acne. pimples, etc. Mung bean starch which is extracted from the mung bean is used to make cellophane noodles which is also called as "bean thread noodles". In South Asia these are used to make "Dhal" which is the common food made out of it. The green gram flour is also used as substitute for wheat flour to enrich the nutritional qualities of the cookies. It is also used as a dietary fibre in gaining importance in human diet. Dietary fibre is generally considered as a unavailable carbohydrate and used 
as mild laxative. The botanical name of green gram is Phasleolus aureus. According to World Health Organization (WHO) medicinal plants are the best source to obtain variety of drug. Pulses have three or four times more protein content than rice and ten to fifteen times more than potatoes

(Mian, 1976).

\section{Materials and methods}

\section{Collection of sample}

The fresh mung bean seeds were collected from the local market in Chennai, Tamil Nadu. The mung bean seeds were carefully rinsed with tap water, rinsed with the distilled water and air dried for one hour. Then the leaves were shade dried for one week at room temperature.

\section{Collection of wound sample}

Due to its significant role in the treatment of skin diseases mung bean play a vital role. So the organisms which are involved in the wound infection are isolated. Wound samples were collected from a private hospital in Chennai.

\section{Preparation of mung bean extracts}

The ground materials of the seeds were extracted using different solvents such as, acetone, choloroform etc. The seeds were finely powdered using mortar and pestle. The extracted seed's powder were dissolved in the solvents in the ratio 1:10 under shaking condition. The extracts were collected in different conical flask and the step was repeated thrice to attain the maximum extraction.

\section{Isolation of microorganisms and biochemical characterization}

The following strains, which are responsible for wound infections are isolated from the sample were used as test pathogens, Pseudomonas sp., Klebsiella pneumoniae, Staphylococcus epidermidis and Staphylococcus aureus. Gram staining and
Biochemical testing were done for the characterization of the microorganism.

\section{Phytochemical analysis}

Phytochemical analysis such as detection of alkaloids, terpenoids, flavonoids, glycosides, proteins, amino acids, etc., were done estimate the level of phytochemicals present in the green gram (Harborne, 1998).

\section{Plant tissue culture}

Callus induction: $0.5 \mathrm{~g}$ of carrot callus medium was weighed and dissolved in $100 \mathrm{ml}$ of tissue culture grade water along with plant agar in a fresh conical flask. Then the medium was sterilized at $121^{\circ} \mathrm{C}$ at $15 \mathrm{lbs}$ pressure. The green gram seeds were washed with distilled water and again rinsed in $70 \%$ ethanol and then again washed with the distilled water. Finally the seeds were washed in $0.1 \%$ mercuric chloride. Then the seeds were inoculated into the carrot callus medium with the sterile forceps. The growth of the explants was observed after 10 days.

Lectin purification and hemeagglutination activity: $10 \mathrm{~g}$ of mung bean seen powder was dissolved in $0.1 \mathrm{M}$ Tirs- $\mathrm{HCl}$ and in $0.01 \mathrm{M} \mathrm{NaCl}$ with $\mathrm{pH} 6.8$ in the ratio 1:5. Then the suspension was left for 3 hours at room temperature in the stirrer. After three hours of suspension the extract is collected and centrifuged at 10,000 r.p.m for 2 minutes. Then the supernatant was collected which contains the purified lectin. The isolated lectin was mixed with $0.25 \mathrm{ml}$ of $2 \%$ human erythrocytes at 1:1 ratio. The agglutination was monitored by incubating the samples for 30 minutes at room temperature.

\section{Antimicrobial activity}

The antimicrobial activity was tested using agar well diffusion method against bacterial (Pseudomonas sp., Klebsiella sp. and Staphylococcus spp.) and fungal species (Aspergillus niger and Candida albicans). 


\section{Antidiabetic activity}

The antidiabetic activity was tested using starch solution as substrate and DNSA as a reagent and reading was measured at $50 \mathrm{~nm}$. The calculation was done using the fomula:

$$
\text { Antidiabetic activity }(\%)=\frac{\text { OD of control }- \text { OD of sample }}{\text { OD of control }} \times 100
$$

\section{Minimum inhibitory concentration}

The MIC of the green gram extract and the green gram callus extract carried against organism was carried out.

\section{Cytotoxicity activity and anticancer activity}

The VERO cell lines was used to study anticancer and cytotoxicity studies of the green gram extract and the green gram callus extract. The formula used was as follows:

$$
\% \text { Cell Viability }=\frac{\mathrm{A} 570 \text { of treated cells }}{\mathrm{A} 570 \text { of control cells }} \times 100
$$

Graphs were plotted using the $\%$ of cell viability at $\mathrm{Y}$-axis and concentration of the sample in $\mathrm{X}$-axis. Cell control and sample control is included in each assay to compare the cell viability assessments.

\section{Results and discussion}

\section{Green gram callus}

The green gram callus seeds were inoculated into the callus medium for the growth of explants. In this study the callus was inoculated into the callus medium without the supplements of vitamins and growth factors. It showed better for the growth of explants without the supplement of vitamins and essential growth factors. In the study reported by Khatun et al. (2008) the regeneration of mung bean took place in 5-7 days of seedling with supply of nutrients such as NAA and BAP. In this study the callus was taken for further analysis without the supply of nutrients.

\section{Extraction}

Two grams of green gram powdered sample was dissolved in $20 \mathrm{ml}$ of water, acetone in the ratio 1:1.

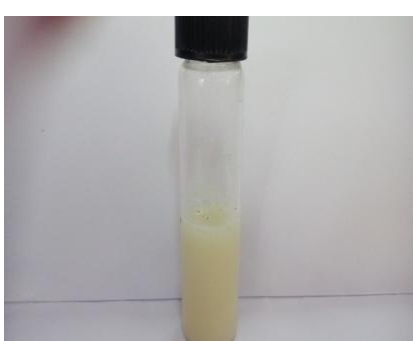

(A)

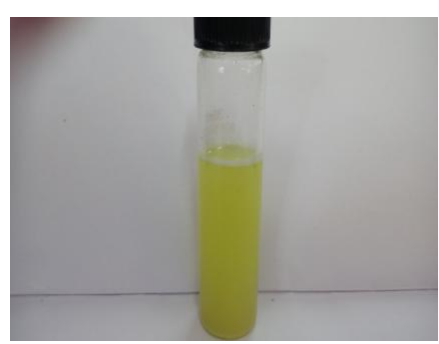

(B)
Fig. 1: Extracts of green gram (A) Water extract; (B) Acetone extract.

Fig. 1 shows the extract of green gram from water (A) and solvent acetone (B) which is very efficient for the further analysis. The green gram seeds are also dissolved in different solvents such as ethyl acetate, methanol and hexane (Ellof, 1998). In this study the sample extracts dissolved in water and acetone showed better results for the application studies

\section{Microscopic examination of the organism isolated and biochemical test}
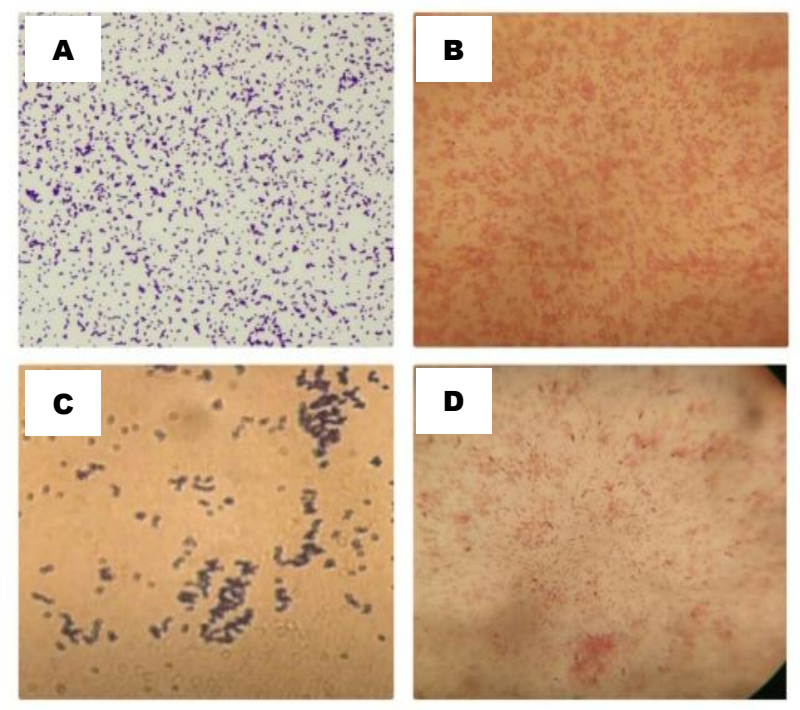

Fig. 2: The microscopic examination of the organism isolated. A. Psuedomonas sp., B. Klebseilla sp., C. Staphylococcus aureus and D. Staphylococcus epidermidis. 
Organisms isolated from the wound samples were innoculated into the medium and they are observed using gram staining under microscope. The microscopic view helps to identify the organism based on their morphology such as cocci, rod etc., In this study the organism isloated as depicted as above in the Fig. 2.

Table 1 confirms from the results that the organism isolated was Pseudomonas sp. The results tabulated in Table 1 to categorise the various types of biochemical tests performed to confirm the presence of organism isolated from the sample. The above table confirms the organism isolated was Pseudomonas $s p$.

Table 2 shows from the result that the organism isolated was Staphylococcus aureus. The Table 2 is tabulated to categorize the various types of biochemical test performed to confirm the presence of organism isolated from the sample. The above table confirms the organism isolated was Staphylococcus aureus.

Table 3 shows from the result that the organism isolated was Klebsiella sp. Table 3 is tabulated to categorise the various types of biochemical test performed to confirm the presence of organism isolated from the sample. The above table confirms the organism isolated was Klebsiella sp.
Table 1. Biochemical characterization of bacterial isolate (Pseudomonas sp.).

\begin{tabular}{ll}
\hline Biochemical tests & Characterisation \\
\hline Simmons Citrate Test & + \\
Urease & - \\
Methyl Red and Voges Proskaur & - \\
Test & \\
Indole Test & - \\
Catalase Test & + \\
Oxidase Test & - \\
\hline
\end{tabular}

Table 2. Biochemical characterization of bacterial isolate (Staphylococcus aureus).

\begin{tabular}{ll}
\hline Biochemical test & Characterization \\
\hline Catalase & + \\
Indole & - \\
Methyl Red & + \\
Urease & + \\
Citrate & + \\
Coagulase & + \\
\hline
\end{tabular}

Table 3. Biochemical characterization of bacterial isolate (Klebsiella sp.).

\begin{tabular}{ll}
\hline Biochemical test & Characterizaton \\
\hline Urease & + \\
Triple Sugar Iron & + \\
Indole & - \\
Oxidase & - \\
Catalase & + \\
Simmons Citarte & + \\
\hline
\end{tabular}

Table 4. Preliminary phytochemical characterization green gram leaves.

\begin{tabular}{lllll}
\hline S.no & Phytochemical tests & Acetone & Choloroform & Water \\
\hline 1. & Protein & + & + & + \\
2. & Amino Acids & + & + & + \\
3. & Cardiac Glycosides & + & + & + \\
4. & Flavanoids & + & + & + \\
5. & Saponins & + & + & + \\
6. & Alkaloids & + & + & + \\
7. & Terpenoids & + & + & + \\
8. & Phenols & + & + & + \\
9. & Sterols & + & + & + \\
10. & Carbohydrates & + & + & + \\
11. & Tanins & + & + & + \\
12. & Quinones & - & - & - \\
13. & Anthroquinones & - & - & - \\
\hline
\end{tabular}


Table 4 shows the phytochemical characterization of the green gram leaf sample. Green gram contains phenols and phenolic compounds such as flavanoids, alkaloids, phenols, sterols atc., From the above table it confirms that green gram contains phenols and phenolic compounds. The phytochemical analysis have been reported in earlier studies which confirms (Santhi and Sengottuvel, 2016) that green gram contains phenols and phenolic compounds.

\section{Lectin purification and hemeagglutination activity}

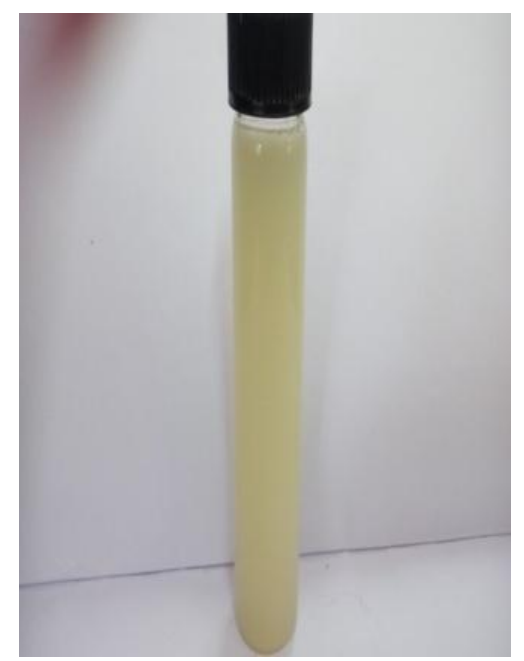

(A)

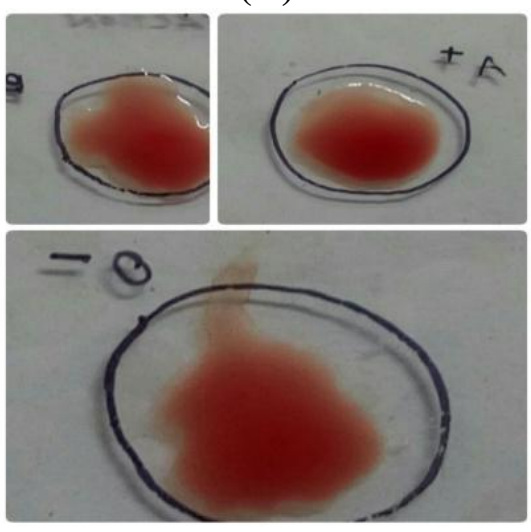

(B)

Fig. 3: (A) Purified lectin; (B) Hemeagglutination activity of lectin.

\section{Antimicrobial activity}

Antimicrobial activity was carried out in green gram powder extract, green gram leaves and green gram callus using four test organism isolates from wound infection.

Table 5. Antibacterial activity of green samples against Pseudomonas sp. expressed in milli meter.

\begin{tabular}{llll}
\hline Organism & Concentration & $\begin{array}{l}\text { Green } \\
\text { gram } \\
\text { powder }\end{array}$ & $\begin{array}{l}\text { Green } \\
\text { gram } \\
\text { callus }\end{array}$ \\
\hline $\begin{array}{l}\text { Pseudomonas } \\
\text { sp. }\end{array}$ & $100 \mu 1$ & $12 \mathrm{~mm}$ & $17 \mathrm{~mm}$ \\
& $150 \mu 1$ & $15 \mathrm{~mm}$ & $19 \mathrm{~mm}$ \\
& $200 \mu 1$ & $18 \mathrm{~mm}$ & $22 \mathrm{~mm}$ \\
\hline
\end{tabular}

Table 6. Antibacterial activity of green gram sample against test organism Klebsiella sp. expressed in milli meter.

\begin{tabular}{llll}
\hline Organism & Concentration & $\begin{array}{l}\text { Green } \\
\text { gram } \\
\text { powder }\end{array}$ & $\begin{array}{l}\text { Green } \\
\text { gram } \\
\text { callus }\end{array}$ \\
\hline Klebsiella $s p$. & $100 \mu \mathrm{l}$ & $13 \mathrm{~mm}$ & $18 \mathrm{~mm}$ \\
& $150 \mu 1$ & $14 \mathrm{~mm}$ & $20 \mathrm{~mm}$ \\
& $200 \mu \mathrm{l}$ & $16 \mathrm{~mm}$ & $24 \mathrm{~mm}$ \\
\hline
\end{tabular}

Table 7. Antibacterial activity of green gram samples against the test organism Staphylococcus aureus expressed in millimeters.

\begin{tabular}{llll}
\hline Organism & Concentration & $\begin{array}{l}\text { Green } \\
\text { gram } \\
\text { powder }\end{array}$ & $\begin{array}{l}\text { Green } \\
\text { gram } \\
\text { callus }\end{array}$ \\
\hline $\begin{array}{l}\text { Staphylococcus } \\
\text { aureus }\end{array}$ & $100 \mu 1$ & $13 \mathrm{~mm}$ & $18 \mathrm{~mm}$ \\
& $150 \mu 1$ & $17 \mathrm{~mm}$ & $20 \mathrm{~mm}$ \\
& $200 \mu 1$ & $19 \mathrm{~mm}$ & $24 \mathrm{~mm}$ \\
\hline
\end{tabular}

Table 8. Antibacterial activity of test organism Staphylococcus epidermidis expressed in milli meters.

\begin{tabular}{llll}
\hline Organism & Concentration & $\begin{array}{l}\text { Green } \\
\text { gram } \\
\text { powder }\end{array}$ & $\begin{array}{l}\text { Green } \\
\text { gram } \\
\text { callus }\end{array}$ \\
\hline $\begin{array}{l}\text { Staphylococcus } \\
\text { epidermis }\end{array}$ & 100 & $10 \mathrm{~mm}$ & $14 \mathrm{~mm}$ \\
& 150 & $11 \mathrm{~mm}$ & $15 \mathrm{~mm}$ \\
& 200 & $13 \mathrm{~mm}$ & $17 \mathrm{~mm}$ \\
\hline
\end{tabular}

\section{Antifungal activity}

Antifungal activity of green gram samples against the test organism Aspergillus niger and Candida albicans is shown in Tables 9 and 10 . 
Table 9. Antifungal activity of green gram samples against the test organism Aspergillus niger expressed in millimeter.

\begin{tabular}{llll}
\hline Organism & Concentration & $\begin{array}{l}\text { Green } \\
\text { gram } \\
\text { callus }\end{array}$ & $\begin{array}{l}\text { Green } \\
\text { gram } \\
\text { extract }\end{array}$ \\
\hline $\begin{array}{l}\text { Aspergillus } \\
\text { niger }\end{array}$ & $100 \mu \mathrm{l}$ & $24 \mathrm{~mm}$ & $12 \mathrm{~mm}$ \\
& $150 \mu 1$ & $26 \mathrm{~mm}$ & $14 \mathrm{~mm}$ \\
& $200 \mu 1$ & $29 \mathrm{~mm}$ & $17 \mathrm{~mm}$ \\
\hline
\end{tabular}

Table 10. Antifungal activity of green gram samples against the test organism Candida albicans expressed in millimeters.

\begin{tabular}{llll}
\hline Organism & Concentration & $\begin{array}{l}\text { Green } \\
\text { gram } \\
\text { callus }\end{array}$ & $\begin{array}{l}\text { Green } \\
\text { gram } \\
\text { extract }\end{array}$ \\
\hline $\begin{array}{l}\text { Candida } \\
\text { albicans }\end{array}$ & $100 \mu \mathrm{l}$ & $14 \mathrm{~mm}$ & $14 \mathrm{~mm}$ \\
& $150 \mu 1$ & $26 \mathrm{~mm}$ & $16 \mathrm{~mm}$ \\
& $200 \mu 1$ & $28 \mathrm{~mm}$ & $18 \mathrm{~mm}$ \\
\hline
\end{tabular}

\section{Antidiabetic activity}

Medicinal plants play an important role in diabetes. From this study $\%$ of inhibition has been evaluated for green gram callus, green gram extract and green gram leaf extract.

Table 11. Antidiabetic activity of green gram callus and extract.

\begin{tabular}{llll}
\hline $\begin{array}{l}\text { Green gram } \\
\text { extract }\end{array}$ & $\begin{array}{l}\text { \% of } \\
\text { inhibition }\end{array}$ & $\begin{array}{l}\text { Green gram } \\
\text { callus }\end{array}$ & $\begin{array}{l}\text { \% of } \\
\text { inhibition }\end{array}$ \\
\hline $0.1 \mathrm{ml}$ & 8.6 & $0.1 \mathrm{ml}$ & 10.3 \\
$0.2 \mathrm{ml}$ & 10.4 & $0.2 \mathrm{ml}$ & 12.4 \\
$0.3 \mathrm{ml}$ & 11.3 & $0.3 \mathrm{ml}$ & 15.7 \\
$0.4 \mathrm{ml}$ & 15 & $0.4 \mathrm{ml}$ & 16.3 \\
\hline
\end{tabular}

From this study the percentage of inhibition depicts green gram samples may have anti diabetic activity which in future may be consumed as drugs. In this study green gram sample has been tested for the future prospects for the consumption as drug.

\section{Cytotoxicity assay}

From Table 12, it has been depicted that the green gram samples are more toxic when compared to green gram callus. Colorimetric method has been performed in order to check the toxic effect of the sample. In this study VERO cell lines have used to enumerate the amount of viable cells present in the sample. Studies are in progress to check the cytotoxicity effect of the cells. In this it has been concluded that the green samples may have a cytotoxic effect.

Table 12. Cytotoxicity assay of green gram callus and green gram extract.

\begin{tabular}{ll}
\hline Sample & \% of inhibition \\
\hline Green Gram Extract & $\mathbf{8 2 . 3 2}$ \\
Green Gram Callus & $\mathbf{2 9 . 3}$ \\
\hline
\end{tabular}

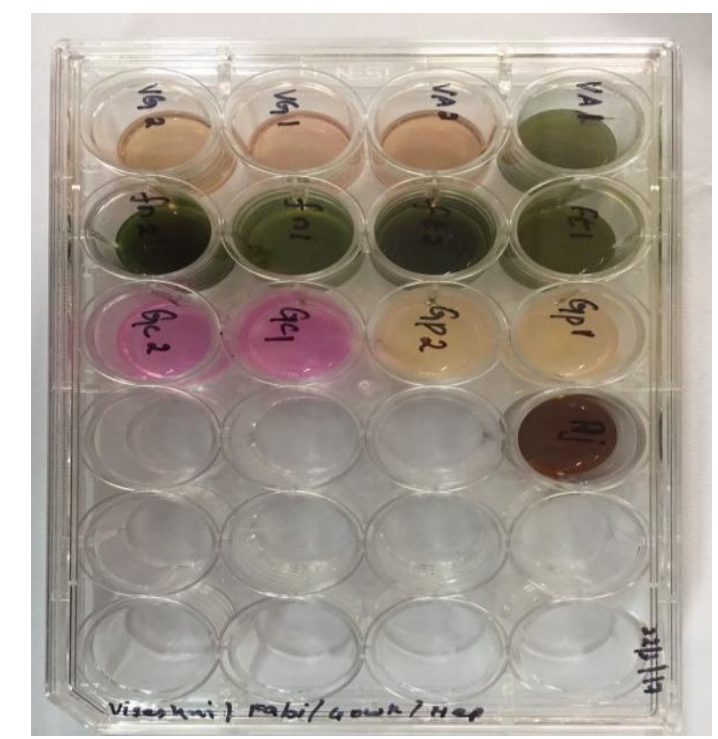

Fig. 4: Inhibition of the green gram callus and extract.

From the above it has been depicted that the green gram extract are toxic to VERO cell lines when compared to green gram callus. The toxicity amount is very much reduced in callus.

\section{Anticancer activity}

The anticancer studies are in process in green gram, the mung bean. In this study anticancer activity has been evaluated to show the effect of sample.

Table 12. Anticancer activity of green gram in lung cancer cell lines.

\begin{tabular}{ll}
\hline Sample & \% of inhibition \\
\hline Green gram callus & 14.8 \\
Green gram extract & 45.2 \\
\hline
\end{tabular}




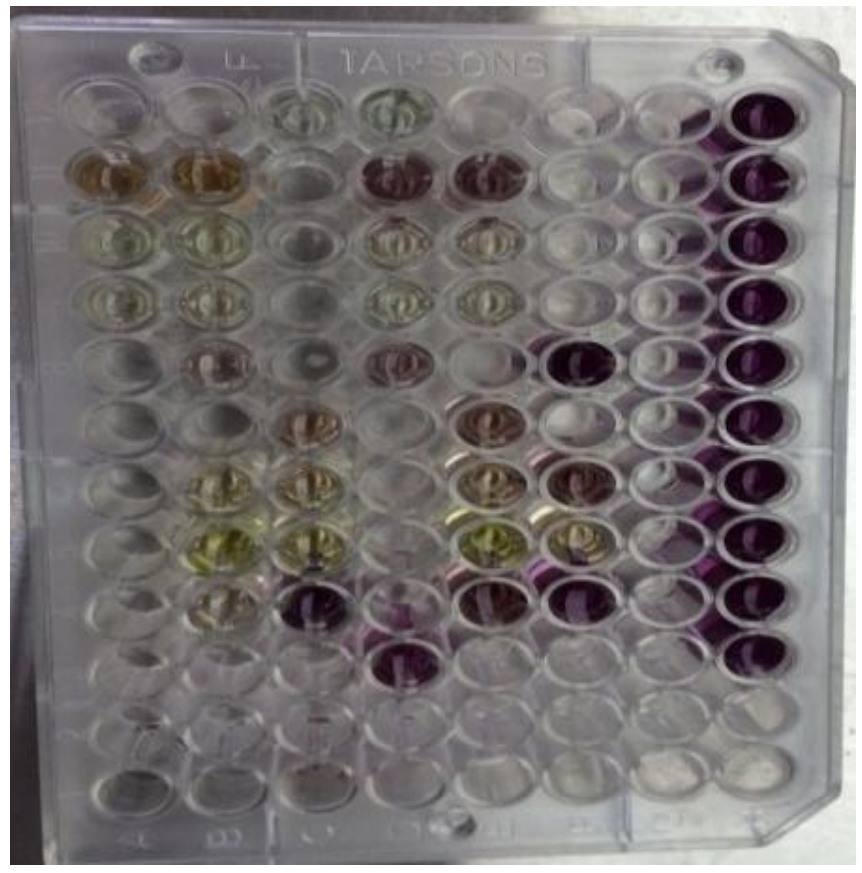

Fig. 5: Anticancer activity of green gram in lung cancer cell lines.

From Table 12 and Fig. 5, it has been depicted that the green gram extract shows more inhibition of the cell lines when compared to green gram callus. From this study it has been evaluated that the green gram samples may have anti cancer activity. Studies have been reported in germination of the seeds to evaluate its activity (Wanget al., 2014). The percentage of inhibition of green gram callus green gram extract was 14.8 and 45.2 respectively.

\section{Conflict of interest statement}

Authors declare that they have no conflict of interest.

\section{References}

Eloff, J.N., 1998. Which extractant should be used for the screening and isolation of antimicrobial components from plants? J. Ethnopharmacol. $60,1-8$.

Harborne, J.B., 1998. Phytochemical Methods: A Guide to Modern Techniques of Plant Analysis. $3^{\text {rd }}$ Edn. Chapman and Hall, London.

Khatun, M. K., Haque, M. K., Islam, S., Nasiruddin, K. M., 2008. In vitro regeneration of mungbean (Vigna radiata L.) from different explants. Progress. Agric. 19(2), 13-19.

Mian, A. L., 1976. Grow more pulses to keep your pulse well an assay of Bangladesh pulses. Department of Agronomy. Bangladesh Agricultural University. Mymensingh. pp. 1-8.

Santhi, K., Sengottuvel, R., 2016. Qualitative and quantitative phytochemical analysis of Moringa concanensis Nimmo. Int. J. Curr. Microbiol. App. Sci. 5(1), 633-640.

Wang, J., Ye, Y., Li, Q., Abbasi, A. M., Guo, X., 2017. Assessment of phytochemicals, enzymatic and antioxidant activties in germinated mung bean (Vigna radiata $\mathrm{L}$. Wilezek). Int. J. Food Sci. Technol. Doi: 10.1111/ijfs.13418.

\section{How to cite this article:}

Gautami, R., Iyer, P., 2018. Antimicrobial and anticancer activity of green gram (Vigna radiata) and callus of green gram. Int. J. Curr. Res. Biosci. Plant Biol. 5(1), 60-66.

doi: https://doi.org/10.20546/ijcrbp.2018.501.008 